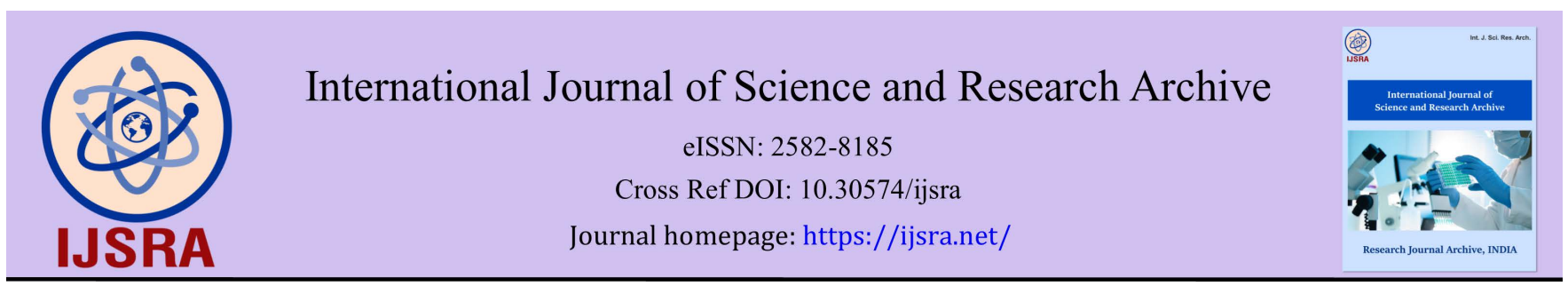

(RESEARCH ARTICLE)

Check for updates

\title{
In vivo immunoloprotective potentials of Plantago lanceolata aqueous extract on methotrexate induced albino male mice
}

\author{
Mohamednoruldin Dh Hazim ${ }^{1}$, Ruqaya Mohammed Al-Ezzy ${ }^{2, *}$ and Ghufran Malek Ealan ${ }^{1}$ \\ ${ }^{1}$ College of Biotechnology, Al-Nahrain University, Baghdad, Iraq. \\ 2 Department of Molecular and Medical biotechnology, College of Biotechnology, Al-Nahrain University, Baghdad, Iraq.
}

International Journal of Science and Research Archive, 2021, 03(02), 168-174

Publication history: Received on 04 September 2021; revised on 10 September 2021; accepted on 12 September 2021

Article DOI: https://doi.org/10.30574/ijsra.2021.3.2.0156

\begin{abstract}
This study aimed to evaluate the immunological potential of Plantago lanceolata through determination of (total and absolute count of white blood cell, total count of red blood cell and total count of hemoglobin). The results indicated the ability of plant extract to modulate toxic effect of methotrexate on albino mice by enhancing immunity through all tested parameters All this effect due to the presence of chemical active constituents of plant especially (flavonoid and alkaloids).
\end{abstract}

Keywords: Plantago lanceolata; Methotrexate; White blood cells; Water extract; Total account; Differential account and albino male mice

\section{Introduction}

The widespread use of Complementary and Alternative Medicine (CAM) is a major importance to today's health care consumers, practitioners, researchers, and policy makers. For example, less than 40 percent of United States people using CAM disclosed such use to a physician. In 1997, an estimated 15 million adults took prescription medications concurrently with herbal remedies or high-dose vitamins, bringing into play the possibility of negative interactions $[1,2]$. History of medicine and plants dates back to remote past when herbal treatment was the only answer to all kind of ailments [3]. Nowadays, greater emphasis is again being laid to phytotherapy all over the world [4]. Herbal medicine is a traditional or folk medicine practice based on the use of plants' seeds, berries, roots, leaves, barks, flowers and plant extracts for medicinal purposes [5], where natural products derived from plants used for the treatment of diseases and show the relationship between the man and his environment [6]. Plantago, a class in the family Plantaginaceae (order Lamiales) with around 265 species. The little plants typically have a thick tuft of basal leaves and long, leafless stalks bearing a terminal spike of little blossoms [7,8]. The plant kingdom contains different genera like: Plantago afra, Plantago bigelovii, Plantago canescens, Plantago debilis (Shade plantain, weak plantain), Plantago erosa, Plantago fernandezia, Plantago gentianoides Plantago heterophylla, Plantago incisa, Plantago krajinai, Plantago lanceolata (Ribwort plantain) etc... [9] Plantago lanceolata historical underpinnings, Plantago gets from the Latin word planta, signifying "young plant" or "sole of the foot". Lanceolata gets from the Latin expression for a lance or spear, and is generally used to demonstrate a species with narrow leaves that taper to a point at one end $[10,11]$

\footnotetext{
${ }^{*}$ Corresponding author: Ruqaya Mohammed Al-Ezzy

Department of Molecular and Medical biotechnology, College of Biotechnology, Al-Nahrain University, Baghdad, Iraq. 


\section{Material and methods}

\subsection{Plant Collection and Identification}

The aerial parts of plants (leaves) from Plantago lanceolata was supplied from the local markets of Baghdad during Sep. / 2020 and recognized by Dr. Ibrahim S. Al-Jubouri, College of Pharmacy, Al-Mustansiriyah University, Iraq.

\subsection{Preparation of Plant Extract}

Aqueous extract of Plantago lanceolata was prepared according to [12] with a weight of 10 grams of plant powder, it was placed in a clean flask and $250 \mathrm{ml}$ of distilled water was added to it, and then it was placed in the shaking incubator at a temperature of $28 \mathrm{C}^{\circ}$ for a period of 30 minutes, then filtered using medical gauze, and then the filtrate was distributed on plates. Dried the water in the oven at $37 \mathrm{C}^{\circ}$ until the water evaporated completely to obtain the dry powder for the aqueous extract. Each sample was placed in sealed tubes, and placed in refrigerator at $4 \mathrm{C}^{\circ}$ until use [13].

\subsection{Laboratory Animals}

Albino male mice (Mus musculus) were the laboratory animals. They were supplied by the Biotechnology Research Centre (Al-Nahrain University). Their ages at the start of experiments were 8-10 weeks, and their weight was 23-27 grains. They were distributed into groups, and each group was kept in a separate plastic cage (details of these groups are given in the section of experimental design). The animals were maintained at room temperature, and had free excess to food (standard pellets) and water (ad libitum).

\subsection{Experimental Design}

Four groups were tested, which each group contain 4 animals' parameters; The total number of animals in this experiment was 16 mice, Details of these groups are summarized in Table 1.

The mice were injected intraperitoneally (IP) as a single dose of plant extract $(0.1 \mathrm{ml})$ per a day for 7 days. Then the mice were sacrificed in day 8 for laboratory assessments.

Table 1 Laboratory tests and number of animals in the investigated groups of experiment number one

\begin{tabular}{|c|l|c|c|}
\hline Group no. & Tested material & $\begin{array}{l}\text { Dose } \\
\text { (mg/kg) }\end{array}$ & $\begin{array}{l}\text { Laboratory tests and } \\
\text { number of animals }\end{array}$ \\
\hline Group I & normal saline (negative controls) & & 4 \\
\hline Group II & Plantago lanceolata aqueous extract & 400 & 4 \\
\hline \multirow{2}{*}{ Group III } & MTX (1 ${ }^{\text {st }}$ and 2ed days) & 200 & \multirow{2}{*}{4} \\
\cline { 2 - 4 } & Plantago lanceolata aqueous extract (3rd to 7th day) & 400 & \multirow{2}{*}{4} \\
\hline \multirow{2}{*}{ Group IV } & MTX & 200 & 16 \\
\hline \multicolumn{2}{|c|}{ The total number of mice in this stage was } \\
\hline
\end{tabular}

\subsection{Immunological parameters}

\subsubsection{Total Count of Leucocytes}

Blood samples were collected by heart puncture using a disposable insulin syringe (1ml). The method of Sood [14] was followed, in which, an aliquot of $0.02 \mathrm{ml}$ blood was mixed with $0.38 \mathrm{ml}$ of leucocyte diluent in a test tube, and left at room temperature for 3 minutes. A drop of the mixture was applied to the surface of Neubauer chamber under the cover slip, and the chamber was left for 3 minutes to settle the cells. The leucocytes were counted in 4 large squares (each with 16 small squares), and the total count of leucocytes was obtained using the following equation:

$$
\text { Total Count }\left(\frac{\text { cell }}{\text { cu. mm. blood }}\right)=\left(\frac{\text { Number of Cells Counted }}{4}\right) \times 20 \times 10
$$




\subsubsection{Absolute Count of Leucocytes}

A drop of blood was smeared on a clean slide and air-dried. The smear was stained with Leishman stain for 5 minutes and buffered for 10 minutes, and then washed with tap water. The slide was air-dried, and then examined under oil immersion lens (100X). At least 100 leucocytes were examined, and percentage of each cell type was recorded, while absolute count of each type of leucocytes was obtained using the following equation [14]:

$$
\text { Absolute Count }\left(\frac{\text { cell }}{\text { cu. mm. blood }}\right)=\left(\frac{\text { Percentage of Cells x Total Count }}{100}\right)
$$

\section{Results}

\subsection{Total white blood cell (WBC) counts}

The typical WBC count in mice the range is 2000 to 10,000 per microliter. This value had been shown in the control negative (group no.1), in which the total count was $4500 \frac{\text { cell }}{\text { cu.mm.blood }}$, as shown in (Table 2).

An increase in the WBC count was observed in mice administered lantago lanceolata (group no.2), the measurement of WBC was $11500 \frac{\text { cell }}{\text { cu.mm.blood }}$ and this can suggests that Plantago lanceolata extract contains terpenes. Administration of terpenoids increased the total antibody production, antibody producing cells in spleen significantly compared to the normal animals indicating its potentiating effect on the immune system. However, there is need to be cautious in administration at high doses to prevent the risk of anemia, (Table 2).

MTX decrease the WBC count, which this appearance at mice (group no.4), in which the total count was 3000 $\frac{\text { cell }}{\text { cu.mm.blood }}$ (Table 2).but when interact Plantago lanceolate with MTX (group no.3), the count increased to 6000 $\frac{\text { cell }}{\text { cu.mm.blood }}$, (Table 2).

\subsection{Differential count of WBCs}

\subsubsection{Total lymphocyte count}

In the control negative group (group no.1), the total lymphocyte count was $2900 \frac{\text { cell }}{\text { cu.mm.blood }}$, as shown in (Table 3).

In mice (group no.2) treated with Plantago lanceolata, lymphocytes increased to $7400 \frac{\text { cell }}{\text { cu.mm.blood }}$, (Table 3).

In mice treated with MTX (group no.4), the lymphocyte count decreased to $1800 \frac{\text { cell }}{\text { cu.mm.blood }}$, which represented $60 \%$ of total WBC, (Table 3); but when interact Plantago lanceolate with MTX (group no.3), the count of lymphocyte approximately same to the normal rang, was $4300 \frac{\text { cell }}{\text { cu.mm.blood }}$, (Table 3).

\subsubsection{Total neutrophils count}

In the control negative (group no.1), the total neutrophils was $1430 \frac{\text { cell }}{\text { cu.mm.blood }}$, (Table 3).

In mice treated with Plantago lanceolata (group no.2), neutrophils count increased to $3370 \frac{\text { cell }}{\text { cu.mm.blood }}$, (Table 3 ).

In mice treaded with MTX (group no.4), the neutrophils increased to $1080 \frac{\text { cell }}{\text { cu.mm.blood }}$ which represented approximately $36 \%$ of total WBC, (Table 3).; but when interact Plantago lanceolate with MTX (group no.3), the result did not show the signification differences in count which approximately same to the control negative, was $1350 \frac{\text { cell }}{\text { cu.mm.blood }}$, (Table 3 ).

\subsection{Total monocytes count}

In the control negative (group no.1), the total count of monocytes was $170 \frac{\text { cell }}{\text { cu.mm.blood }}$, (Table 3).

In mice treated with Plantago lanceolata (group no.2), monocytes count increased to $730 \frac{\text { cell }}{\text { cu.mm.blood }}$, (Table 3). 
In mice treaded with MTX (group no.4), the count of monocytes approximately preserved in normal level, was 120 $\frac{\text { cell }}{\text { cu.mm.blood }}$, (Table 3); but when interact Plantago lanceolate with MTX (group no.3), monocytes count increased approximately to $6 \%$ of total WBC, was $730 \frac{\text { cell }}{\text { cu.mm.blood }}$, (Table 3 ).

Table 2 The mean of total WBC count in albino male mice

\begin{tabular}{|l|c|c|}
\hline Group no. & Dose (mg/kg) & Mean of total WBC count $\frac{\text { cell }}{\text { cu.mm.blood }}$ \\
\hline negative controls (Group I) & & 4500 \\
\hline Plantago lanceolata aqueous extract (Group II) & 400 & 11500 \\
\hline Plantago lanceolata + MTX (Group III) & $400+200$ & 6000 \\
\hline MTX (Group IV) & 200 & 3000 \\
\hline
\end{tabular}

Table 3 The mean of differential Lympho., Neutro., Mono., in albino male mice

\begin{tabular}{|l|c|c|c|c|}
\hline \multirow{2}{*}{ Group no. } & \multirow{2}{*}{ Dose (mg/kg) } & Lympho & Neutro & Mono \\
\cline { 3 - 5 } & & \multicolumn{2}{c|}{ cell/cu.mm.blood } \\
\hline negative controls (Group I) & & 2900 & 1430 & 170 \\
\hline Plantago lanceolata aqueous extract (Group II) & 400 & 7400 & 3370 & 730 \\
\hline Plantago lanceolata+ MTX (Group III) & $400+200$ & 4300 & 1350 & 350 \\
\hline MTX (Group IV) & 200 & 1800 & 1080 & 120 \\
\hline
\end{tabular}

\subsection{Total red blood cell ( $R B C)$ count}

Total RBC count in control negative (group no.1), mice was $6.58^{*} 10^{12}$ cell/L, but these count increeased to $7.66^{*} 10^{12}$ cell/L and $7.64 * 10^{12}$ cell/L when mice treated with Plantago lanceolate and Plantago lanceolata with MTX respectively, while MTX reduce count to $6.05^{*} 10^{12}$ cell/L, table no. (4),

Table 4 The total RBC count in albino male mice

\begin{tabular}{|l|c|c|}
\hline Groups & Dose (mg/kg) & Total RBC count /L \\
\hline Control negative (Group no.1) & ----- & $6.58^{*} 10^{12}$ \\
\hline Plantago lanceolata (Group no.2) & 400 & $7.66^{*} 10^{12}$ \\
\hline Plantago lanceolata + MTX (Group no.3) & $200+400$ & $7.64^{*} 10^{12}$ \\
\hline MTX (Group no.4) & 200 & $6.05^{*} 10^{12}$ \\
\hline
\end{tabular}

\subsection{Hemoglobin (Hb or Hgb)}

Table 5 Total Hb count in albino male mice

\begin{tabular}{|l|c|c|}
\hline Groups & Dose (mg/kg) & Total Hb count (g/dL) \\
\hline Control negative (Group no.1) & ----- & 12.7 \\
\hline Plantago lanceolata (Group no.2) & 400 & 11.0 \\
\hline Plantago lanceolata + MTX (Group no.3) & $200+400$ & 11.7 \\
\hline MTX (Group no.4) & 200 & 10.0 \\
\hline
\end{tabular}


Total $\mathrm{Hb}$ in all group were $(12.7 \mathrm{~g} / \mathrm{dL}, 11.0 \mathrm{~g} / \mathrm{dL}, 11.7 \mathrm{~g} / \mathrm{dL}, 10.0 \mathrm{~g} / \mathrm{dL}$ ) for (Control negative (Group no.1), treated with Plantago lanceolata (Group no.2), treated with Plantago lanceolata and MTX (Group no.3), treated with MTX (Group no.4)) respectively. Which did not show significant different between them, table no. (5)

\section{Discussion}

Known for centuries throughout the world, Plantago species have long been used as traditional herbal remedies for many diseases related to immunity and respiratory tract, or even in; digestive tract, malignancy, etc.

Plants have been used since antiquity to treat and prevent diseases. Plantain (Plantago lanceolata) is traditionally used for the treatment of the common cold and associated symptoms such as cough [15]. At present, the pharmacological effect of the drug cannot be definitively ascribed to one single constituent or a group of compounds.

Plantain (Plantago lanceolata) is one of the perennial herbs having some bioactive compounds such as caffeic acid derivatives (in particular acteoside), iridoid glycosides (are aucubin, catapol) [16,17], which have anti-oxidative activity [18]. Plantago lanceolata dry extract is a complex mixture of phytochemical substances [19].

One of the main constituents in Plantago lanceolata is the caffeic acid ester acteoside (also known as verbascoside). Further characteristic constituents are the iridoid monoterpenes aucubin and catalpol, isoacteoside and chlorogenic acid. As long as there is no definitive association between clinically observed efficacy and an identified constituent of fraction, a standardization to a defined content of this substance or fraction is not possible. The definition of a minimum content of dihydroxycinammic acid derivatives in plantain herb (calculated as acteoside) according to the European Pharmacopoeia monograph is merely a marker for the assurance of sufficiently well-defined quality. It was therefore selected as a marker compound for plantain extract and plantain syrup as well [20].

The European medicines agency (EMA), community herbal monograph on the traditional use of plantain as a herbal medicinal product does not state any known adverse effects or contraindications beyond the usual warning against the possibility of hypersensitivity [21]. In fact, there seems to be only the report of Ozkol on two suspected cases of phototoxic reactions after oral consumption of Plantago lanceolata preparations followed by exposure to sunlight $[22,23]$. Such cases have never been previously reported in the literature and from clinical experience. Phototoxicity would not be covered by our study design, but appears rather unlikely in view of the worldwide experience with plantain exposure. Some scientist founded that, Plantago lanceolata extract showed no signs of toxicity in rats in oral administration as syrup within the specified dose. This finding is in line with literature data: have found that Plantago was not toxic. $[21,24,25]$.

\section{Conclusion}

The present study showed that Plantago lanceolata leaf extract has a significant increase in total white blood cell and differential white blood cell counts in normal mice, after intraperetoial administration of the extract may promote the immune-stimulatory activities. These stimulant effects could be associated with the adjuvant activity chemical constituents in plant (flavonoid, al-kaloide, terpenoids, caffeic acid derivatives, iridoid glycosides, fatty acids, polysaccharide, vitamins). found in the extracts hence which can be used in management of immune dependent disorders.

\section{Compliance with ethical standards}

\section{Acknowledgments}

Special thanks submitted to staff of Biotechnology Research Center \Al-Nahrain University.

\section{Disclosure of conflict of interest}

There was no conflict of interest.

\section{Statement of ethical approval}

This work done after take a permission from the head of animal laboratory house $\backslash$ Biotechnology Research Center $\backslash$ AlNahrain University \Baghdad \Iraq. 


\section{References}

[1] Micozzi MS. Fundamentals of complementary and alternative medicine-E-book. Elsevier Health Sciences. 2014.

[2] Nyedua SOA. Integration of traditional and alternative medicine into routine health care delivery system in the Kumasi Metropolis of Ashanti Region, Ghana (Doctoral dissertation). 2020.

[3] Welz AN, Emberger-Klein A, Menrad K. Why people use herbal medicine: insights from a focus-group study in Germany. 2018.

[4] Biomedcentral complementary and alternative medicine. 18(1): 92.

[5] Raman RP. Applicability, feasibility and efficacy of phytotherapy in aquatic animal health management. American Journal of Plant Sciences. 2017; 8(02): 257.

[6] Parkash J, Prasad DN, Shahnaz M, Dev D. Herbs as traditional medicines: A review. Journal of Drug Delivery and Therapeutics. 2018; 8(5): 146-150.

[7] Koparde AA, Doijad RC, Magdum CS. Natural products in drug discovery. In Pharmacognosy-Medicinal Plants. 2019.

[8] Singh SN, Srivastava S. Traditional biomedical knowledge of Measles, Mumps and Rubella (MMR): A critical review. International Trends in Library and Information Technology. 2017; 4(2): 2-30.

[9] Igberaese PO, Ogbole 00. Ethnobotanical survey of plants used in the treatment of typhoid and its complication (s) in Esan North East local government area, Uromi, Edo state. Nigerian Journal of Pharmaceutical Research. 2018; 14(2): 175-188.

[10] Mintah SO, Asafo-Agyei T, Archer MA, Junior PAA, Boamah D, Kumadoh D, Agyare C. Medicinal plants for treatment of prevalent diseases. In Pharmacognosy-Medicinal Plants. Intech Open. 2019.

[11] Chakraborty P. Herbal genomics as tools for dissecting new metabolic pathways of unexplored medicinal plants and drug discovery. Biochimie open journal. 2018; 6: 9-16.

[12] Jamshidi-Kia F, Lorigooini Z, Amini-Khoei H. Medicinal plants: Past history and future perspective. Journal of herbmed pharmacology. 2018; 7(1).

[13] Velasco-Lezama R, Tapia-Aguilar R, Román-Ramos R, Vega-Avila E, Pérez-Gutiérrez MS. Effect of Plantago major on cell proliferation in vitro. Journal of Ethnopharmacology. 2006; 103(1): 36-42.

[14] Rios JL, Recio MC, Villar A. Screening methods for natural products with antimicrobial activity: a review of the literature. Journal of Ethnopharmacology. 1988; 23(2-3): 127-149.

[15] Sood R. Hematology for Students and Practitioners. Jaypee Brothers, New Delhi, India. 1986.

[16] Silveira D, Prieto-Garcia JM, Boylan F, Estrada O, Fonseca-Bazzo YM, Jamal CM, Heinrich M. COVID-19: Is there evidence for the use of herbal medicines as adjuvant symptomatic therapy?. Frontiers in Pharmacology. 2020; 11: 1479.

[17] Ishiguro K, Yamaki M, Takagi S. Studies on the iridoid related compounds. I. On the antimicrobial activity of aucubigenin and certain iridoid aglycones. Yakugaku zasshi: Journal of the Pharmaceutical Society of Japan. 1982; 102(8): 755-759.

[18] Nishibe S, M Murai. Bioactive components of Plantago herb. Foods Food Ingr. J. 1995; 166: 43-49.

[19] Wang P, Kang J, Zheng R, Yang Z, Lu J, Gao J, Jia Z. Scavenging effects of phenylpropanoid glycosides from Pedicularis on superoxide anion and hydroxyl radical by the spin trapping method (95) 02255-4. Biochemical Pharmacology. 1996; 51(5): 687-691.

[20] Budzianowska A, Budzianowski J. A new flavonoid, a new phenylethanoid glycoside and related compounds isolated from the inflorescences of Plantago lanceolata L. Natural Product Research. 2021; 1-12.

[21] Fleer H, Verspohl EJ. Antispasmodic activity of an extract from Plantago lanceolata L. and some isolated compounds. Phytomedicine. 2007; 14(6): 409-415.

[22] Mansoor K, Qadan F, Schmidt M, Mallah E, Abudayyih W, Matalka K. Stability study and a 14-day oral dose toxicity in rats of plantain leaf extract (Plantago lanceolata L.) syrup. Scientia pharmaceutica. 2017; 85(1): 15.

[23] Ozkol HU, Akdeniz N, Ozkol H, Bilgili SG, Calka O. Development of phytophotodermatitis in two cases related to Plantago lanceolata. Cutaneous and ocular toxicology. 2012; 31(1): 58-60. 
[24] Nguyen DA, Muhammad MK, Lee GL. Background / Introduction. Dermatological Manual of Outdoor Hazards. 2020; 43.

[25] Lim-Sylianco CY, Shier WT. Mutagenic and antimutagenic activities in Philippine medicinal and food plants. Journal of Toxicology: Toxin Reviews. 1985; 4(1): 71-105.

[26] Ruiz AR, De la Torre RA, Alonso N, Villaescusa A, Betancourt J, Vizoso A. Screening of medicinal plants for induction .of somatic segregation activity in Aspergillus nidulans. Journal of Ethnopharmacology. 1996; 52(3): $123-127$. 